existed only in Lagos and Accra, and in modified forms elsewhere, but he was taking steps to start a gymkhana in Sierra Leone, and was assured that if the necessary funds would be forthcoming for its establishment it would be maintained by annual subscriptions. The West African Englishman ought to have opportunities of taking vigorous exercise like his brother in India, and greater attention should be given to providing him with suitable food. Fresh milk, butter, and eggs were very hard to procure on the West Coast. In every principal settlement there should be a " settlement farm," where attempts should be made to grow vegetables and to keep cattle and fowls, so as to provide meat and dairy produce. He believed that if private subscriptions were forthcoming to pay the initial expenses, which would not be large, the Government would meet the enterprise half way. Again, in India a bottle of soda water cost a halfpenny, and ice could be obtained from local machines almost everywhere, while in Africa a bottle of aërated water cost $6 \mathrm{~d}$. and ice could not generally be got. He thought the principal business houses should band together in order to arrange for ice and soda-water factories, and he believed that the Government would be a fixed customer for the hospitals and the troops. He had also been struck by the general absence of punkahs. Punkahs and electric fans had been introduced into the house occupied by the expedition in Freetown, and there was no reason why their use should not be extended. It was said that horses would not live in Sierra Leone and some other places, but this was probably due to some preventable parasitic disease, and he thought it astonishing, considering the economic importance of horses, that the Government should not long ago have ordered an investigation into the cause of their mortality. At Sierra Leone there was an excellent site on the hills close to Freetown for a residence for Europeans, and when this was rendered accessible by the tramway shortly to be provided, he hoped that advantage would be taken of it by merchants for the residence of persons employed by them on the coast. The School had two watchwords for the improvement of the health of Europeans on the West Coast: (1) No stagnant water ; (2) greater comfort for Europeans.

\section{THE ANDERSON FUND.}

The Committee formed to appeal for aid for the widow and two sons of the late Mr. R. B. Anderson, F.R.C.S., beg to announce the following additional list of subscriptions from July 26th to October 22nd. The total amount now subscribed is 73 guineas.

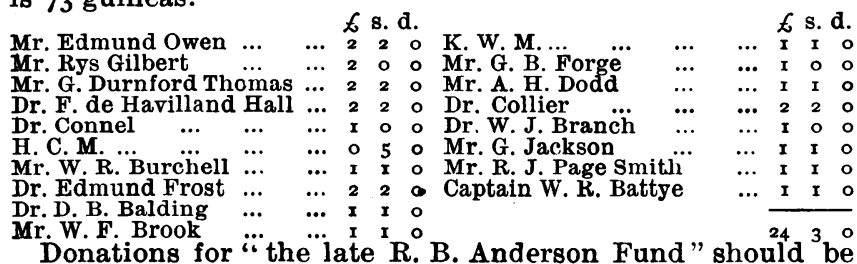

Donations for " the late R. B. Anderson Fund" should be sent and made pavable to the Manager, Union Bank of London, Chancery Lane, London.

As it is proposed to close the Fund at an early date, intending subscribers are requested to send in their donations without delay.

The Earl of Stamford is Chairman; Mr. Timothy Holmes, F.R.C.S., Honorary Treasurer; Mr. Walter Moninngton, 7. Fig Tree Court, Temple, E.C., Honorary Secretary.

\section{AN APPEAL.}

Sir,-Kindly permit us through the columns of the BritisH MEDical Journal to ask for contributions to a fund we are raising on behalf of the family of the late $\mathrm{Mr}$. W. Kortwright Brock, M.R.C.S., L.S.A. (formerly on the A.M.S., but obliged to leave the service on reduction of the staff), whose untimely death, owing to an accident, left in very straitened circumstances a widow and eight children.

It is specially on behalf of one of these children that we are anxious to collect as soon as possible a sufficient sum to enable him to obtain a living for himself, and eventually help the rest of the family. He has shown a great aptitude for pharmacy, and if the opportunity now offered can be taken advantage of, he will be earning before long a respectable competency.

We appeal with confidence to your readers for contributions, which will be gratefully acknowledged by Mr. B. Jones, Balcarras, Wells Road, Knowle, Bristol, who has consented to act as Honorary Secretary to the Fund. Cheques should be drawn in favour of the Honorary Treasurer, Mr. E. H. C. Pauli, and crossed "Lloyd's Bank, Limited, Temple Gate, Bristol Branch-Brock Fund."-We are, etc.,

Georae Dunhop,

The Vicarage, Knowle, Bristol

E. H. C. PAULI, M.R.C.S., L.R.C.P.Lond., Alma Villa, Knowle, Bristol.

Charles Steele, M.D., F.R.C.S.Eng. Clifton Villa, Clifton.

James Stewart, B.A., F.R.C.P.Edin., Bristol, Oct. rsth. Dunmurry, Sneyd Park, Clifton.

\section{THE PLAGUE.}

\section{Prequlenoe of the Dishase.}

INDIA.

THE improvement recorded during the week ending September 21st was not maintained. for the mortality from plague for all India amounted to 7,279 in the week ending September 28 th, against 6,386 and 5,612 during the weeks ending September 14 th and 2 rst the vilulence of the disease at this season looked for, and the hope or a break in the increasing mortality which was fecordod our last issue from plague is confined for the most part to the Bombay districts, where, out of the total number of deaths, 6.499 occurred in these districts alone. In comparison with these figures the plague deaths in other localities are quite insignificant. During the weeks ending September 2rst and September 28 th respectively, the deaths from plague were: In Bombay city, 236 and 233 in Calcutta, 13 and 16 ; in Bengal, 72 and 99 ; in the Punjab, 57 and 9o; in the North-West Provinces, 18 and 28 ; in the Mysore State, 342 and 29o. Plague seems to have recurred in the Benares district, as during district, also, to deaths from plague were notified during the same period.

CAPE OF GoOD Hope.

During the week ending October i2th, no fresh case of plague occurred At Port and one death from the disease. A telegram dated Cape Colony, October 6th states that Dr. Kirkton, plague officer at Port Elizabeth, has con tracted plague. Additional plague precautions have been proclaimed in the Cape Peninsula and at all ports and coastal towns in Cape Colony.

$$
\text { Naples. }
$$

A telegram dated Rome, October 17 th, announces that " an order from the Maritime Health Office states that ten days having elapsed since the isolation of the last patient attacked by plague at Naples, without any fresh cases being reported either at Naples or elsewhere, the order of September 25 th, which was directed against arrivals from Naples, has been withdrawn. On October r8th the
publication of plague bulletins.

TURKEY.
Four cases of plague were reported in the Galata quarter of Constan Four cases of plague were reported in the Galata quarter of Constantinople on October $17 \mathrm{th}$. All the patients belonged to a Greek family. At sairn suffering from plague. The sanitary authorities were not made sailor suffering from plague. The sanitary authorities were not made acquainted with the fact that the patient was suffering from plague, and wes to what is called the French Hospital at Smyrna.

\section{EGYPT.}

According to a telegram dated Cairo, October 2rst, the total numer of cases in all Egypt on that date was 5 . Of this number, Europeans) were reported from Alexandria, and 3 (1 European and natives) at Mit Ghamr. Since the outbreak of April 7 th of this year 18 作 fatally, 89 have been cured, and 5 remain under treatment.

A Scientific Food Experiment in Chicago.-According to the New York Medical Journal, children of wealthy parents are to be the subjects of scientific food experiments in a splendidly-equipped home known as the Chicago Hospital School for Nervous and Delicate Children. The home can accommodate only fifteen children and the applications largely exceed the accommodation. An annexe is to be established soon, and the effects of food on the brain and body are to be studied under the direction of Dr. John M. Dodson, Dean of the Rush Medical School, who is the originator of the idea. All conventional ideas of a school are to be disregarded: there will be no desks, and nothing else suggestive of an educational institution. The hospital school is affiliated with Rush College. 